\title{
ADVANCED PROCESS FOR THERMAL TREATMENT OF WASTEWATER SLUDGE
}

\author{
Mika Horttanainen \\ Juha Kaikko \\ Riikka Bergman \\ Katja Kakko \\ Hanna-Mari Manninen \\ Esa Marttila \\ Lappeenranta University of Technology, Finland
}

\begin{abstract}
In addition to composting and anaerobic digestion, thermal treatment is one of the most important treatment methods of wastewater sludge. There are special sludge incineration plants, built for large volumes of wastewater sludge. Sludge is also burned with other fuels, especially in the forest industry. Energy from the combustion process is usually utilized as heat only or in combined heat and power production. Combustion diminishes the volume of the sludge by 80 to $96 \%$ depending on the moisture and ash content of the sludge. The delay time of the material in the combustion process is a few seconds as opposed to several days in biological processes. At the same time, all the pathogens are completely destroyed. The challenges in combustion are often related to the high moisture content of the sludge, which can cause problems to the stability of the combustion. Sludge can be dried thermally before combustion to avoid these problems.
\end{abstract}

In this study, we introduce the modeling results of a sludge treatment process based on thermal drying and combustion. The process utilizes the released energy in distributed electricity production.

The process under review burns the dried sludge and produces high-pressure steam in a normal power plant process. The steam is led to the turbine where heat is converted to mechanical energy. After the backpressure turbine, the steam still contains a lot of thermal energy. In the case study this heat is not used for district heating or industrial process heating purposes but utilized totally for sludge drying. One advantage of this process is that no heat load is required at the sludge treatment plant, often situated far from district heating networks or industry. The need for mechanical drying of sludge can also be optimized to save in the costs of the mechanical drying facilities and energy. With the example case it is shown how the pre-treatment, thermal drying and combustion should be designed to achieve a purely electricity producing process which does not need any other sources or consumption of energy.

\section{KEYWORDS}

Sludge; Thermal treatment; Combustion. 
Kalmar ECO-TECH

KALMAR, SWEDEN, November 26-28, 2007

\section{INTRODUCTION}

In the developed countries, the volume of sewage sludge has increased rapidly during the past decades. The percentage of the households connected to the sewage system and central wastewater treatment plants has grown because of legislative changes. The EU legislation requires that all sewage waters from communities with at least 2,000 inhabitants have to be treated so that the sensitivity of the receiving waters is taken into consideration [1]. Increasing quantities of wastewater sludge have brought about the need to develop sludge treatment technologies. The technologies aim at reducing the volume and mass of the sludge, eliminating the microbial activity and pathogens, reducing odor release and recovering nutrients and/or energy of the material. Legislation has been developed to steer the treatment of the sludge so that these objectives can be achieved. The EU countries have set targets for decreasing landfilling of biodegradable waste [2], landfilling of untreated biodegradable waste is mostly banned, and there is a special Sewage Sludge Directive [3] which prohibits the use of untreated sludge for agricultural purposes and sets other restrictions for it. In the future, similar development can be expected in the so-called newly industrialized countries and in developing countries. These factors increase the need of technology development for sewage sludge treatment and recovery.

The problems in the operation of sludge treatment technologies have caused offensive odor gas emissions. Legislative restrictions and negative attitudes have resulted in poor demand for compost products in soil enhancement and agricultural purposes. Combustion of sludge has several advantages compared with biological treatment. Mass and volume reduction is significantly more effective. After combustion, the only residue is ash that accounts for about $10-30 \%$ of the dry solids, and the total mass has decreased by more than $90 \%$ from the mechanically dewatered mass. In biological treatment, the reduction of mass is usually in magnitude of $10-50 \%$, depending on the technology (composting, anaerobic digestion), amendment addition and mechanical treatment after the biological stabilization. The destruction of pathogens is complete in combustion because no living organisms can survive in temperatures above $850 \mathrm{aC}$, which is the demand for incineration of waste materials. After biological treatment, there is a higher risk of pathogens in the product because there can be parts of material, which have not mixed or reacted completely and the temperatures are only 50-70aC. The total energy content of the organic material can be recovered in combustion but a large share of it is consumed to evaporation of water. Organic material and some parts of nutrients are lost in combustion, but in principle it is possible to utilize phosphorous and some other inorganic nutrients from the ash. The concentrations and leachability of the heavy metals have to be in an acceptable range if the ash is recovered.

During the 1990s, more than 7 million tons of sewage sludge (dry solids) was generated in the EU and about 6.9 million tons in the USA. The share of incineration varied from 0 to over $30 \%$ in different countries $[4,5]$. The commonly used incineration technologies were multiple hearth furnaces (MHF) and fluidized bed combustor (FBC) (Figure 1). Both technologies can be used in mono-combustion of sludge only, but FBC is used also for other fuels and in cocombustion of sludge and other fuels. The advantages of FBC compared to most of the other technologies are good mixing of the fuel (fluidized with the inert bed material), thermal 
stability of the combustion because of the heat capacity of the bed material, and relatively long residence time of the particles in the furnace. Therefore the combustion of particles and volatiles is complete, with a small need for excess air. The furnace maintenance costs are small because there are no moving parts in hot conditions. Both mechanically dewatered and thermally dried sludge can be burned in FBC. Most of the existing incineration plants are designed for centralized treatment of wastewater sludge (magnitude 5,000-50,000 t/yr dry solids) [4].



(a)



(b)

Figure 1. Multiple hearth furnace (a) [t] and a fluidized bed combustor (b).

The growing demands for waste treatment have promoted a development whereby sludge is increasingly treated in regional waste treatment plants. These plants are usually not in the immediate vicinity of residential areas. For this reason, there is often lack of heat load for sludge treatment plants. In these cases it would be useful to convert the energy from sludge combustion effectively to electricity. Most of the earlier technologies have been economical only as large-scale applications, which has been an obstacle to countries like Finland to apply the mono-incineration of sludge.

\subsection{Cultural acceptability of transforming waste to energy}

This study has been performed under the project "Waste-to-Energy - A modular CHP plant utilizing municipal waste streams in distributed energy production". A crosscutting theme in this project is based on the cultural significance of disposal and the social acceptability of a new technology. In order to gain success for a new technology or a product, diffierent user groups must approve the technology and willingly use it. In order to achieve this goal, we 
have to understand the dominant cultural elements and the influence of these elements on developing and launching a new technology or product.

Cultural acceptability of a new technology is easily disregarded during the technical development of a new innovation into a product. Additionally, traditional business research is often concentrated on economic facts, such as the product's cost-benefit analysis, and this view dominates as the main interpretive factor when investors' and other actors' decisionmaking processes are explained. However, the decision-making process in purchasing a new technology is not only based on profit seeking, nor is production or use of a product or technology only based on satisfying onesà needs. In the Waste-to-Energy context, cultural research related to a new technology is even more complicated as explained above, as a cultural status of waste is never completely neutral. Goods do not simply convert to destroyable waste as they go out of date or break down, but regardless of whether they are usable or not, they may be emotionally highly valuable. The diffierence between waste and nowaste may in many occasions be difficult to determine. According to an anthropological classic Purity and Danger [6], waste is material in a wrong context and disorder by essence.

However, the meaning of waste has changed considerably during the past few years along with the fear of insufficiency of energy and the global concern for the current environmental status quo. The character of disposal in a present-day western culture is defined by numerous diffierent classifieation principles, through which people compose culturally accepted views of goods and goods changed into waste. The classifieation principles are based on hygienic understanding, economic views, dominant moral and hierarchy, and a positive atmosphere related to recycling [7]. During this research project, the preconditions for approving the plant in a community will be examined, i.e. how different actors influence the acceptance of a new technology among the end users and other stakeholders.

\subsection{Objectives of the study}

In this study we introduce an advanced thermal treatment process of wastewater sludge based on thermal drying and fluidized bed combustion. The process is developed for distributed energy production and can be adapted to power only or combined heat and power (CHP) applications using sludge, other waste materials and biomass as fuels. It is designed especially for small-scale sludge treatment, and in this article, we focus on power production possibilities using sludge as the only fuel. The process is designed so that thermal energy from the combustion of dried sludge is first recovered in the steam turbine for power production and the rest of the heat of steam is used for the thermal drying of the sludge.

\section{SLUDGE TREATMENT BEFORE THERMAL PROCESSING}

Most of the volume of the sewage sludge coming from the wastewater treatment process is water. Before the combustion of sludge, the moisture content has to be decreased so that the thermal treatment can be performed without extra energy. The water content is decreased at the wastewater treatment plant with clarification, thickening, chemical conditioning and mechanical drying (Figure 2). After thickening, the dry solids (DS) content of the sludge is typically $2-10 \%$ [8]. With mechanical drying (e.g., solid-bowl centrifuge, belt-filter press) it is 
usually possible to increase the solids concentration to $20-25 \%$ and even higher $(25-35 \%)$ if conditioning chemicals are used. The result of mechanical drying is significantly inflaenced by the composition of the sludge.

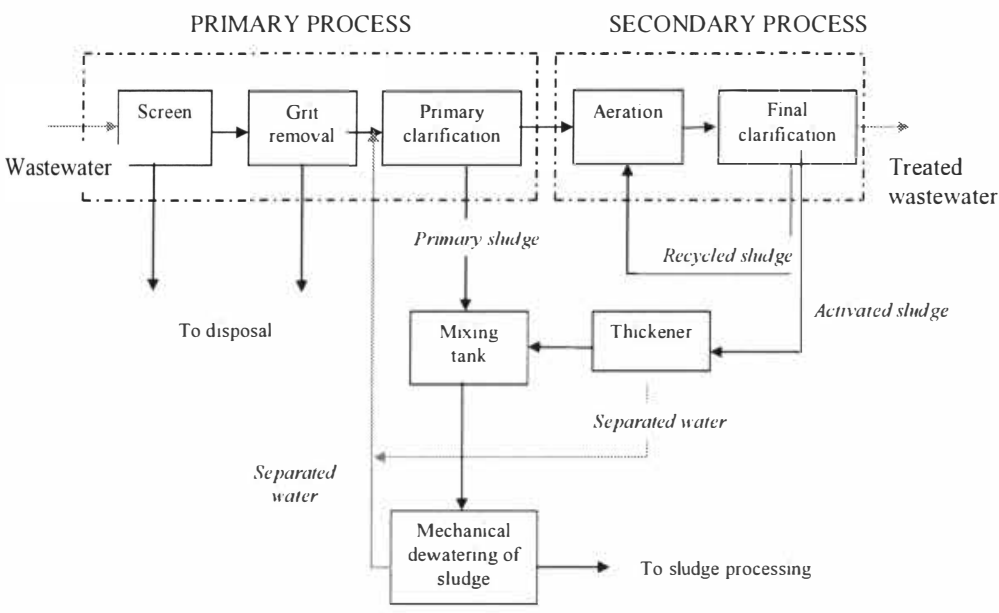

Figure 2. A schematic figure of the wastewater treatment plant and sludge separation.

The composition of the dry matter of sludge is important for the combustion because it can no longer be affiected after the wastewater treatment process. Typical elemental compositions and lower heating values of the dry solids of sewage sludge are presented in Table 1 . The values selected for the example discussed in the following chapters are also presented.

\section{MODELING OF THE DRYING AND COMBUSTION PROCESS}

The developed thermal sludge treatment plant is based on a steam power (Rankine) cycle and is equipped with a drum-type boiler and a backpressure turbine. The circulating fluidized bed (CFB) technique is used for drying the sludge thermally in a commercial indirect CFB dryer and incinerating the dried sludge and odorous vapor in a constant temperature combustion (CTC) reactor. A schematic layout of the plant is presented in Figure 3. 
Table 1. Elementary compositions and heating values of primary and secondary sludge (in dry matter) (Niessen 2002).

\begin{tabular}{ccc}
\hline Element/property & $\begin{array}{c}\text { Range } \\
(\mathrm{m}-\%)\end{array}$ & $\begin{array}{c}\text { Example case } \\
(\mathrm{m}-\%)\end{array}$ \\
\hline $\mathrm{C}$ & $28-50$ & 50 \\
\hline $\mathrm{H}$ & $3-8$ & 7 \\
\hline $\mathrm{N}$ & $2-5$ & 4.8 \\
\hline $\mathrm{O}$ & $15-25$ & 15.2 \\
\hline $\mathrm{S}$ & $0.4-0.9$ & 0.9 \\
\hline $\mathrm{Ash}$ & $22-47$ & 22.1 \\
\hline Total & - & 100 \\
\hline Lower heating value $(\mathrm{MJ} / \mathrm{kg})$ & $12-23$ & 23 \\
\hline
\end{tabular}

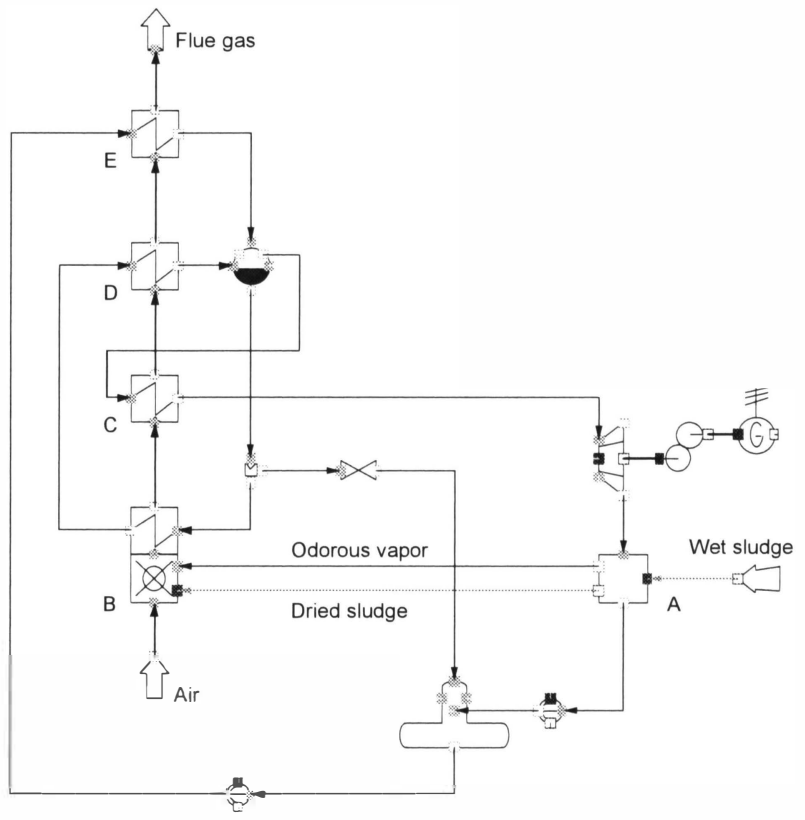

Figure 3. Layout of the thermal sludge treatment plant (A CFB dryer, B CTC reactor including evaporator I, C superheater, D evaporator 2, and E economizer).

In the boiler, the feed water is pre-heated, evaporated in two consecutive stages and superheated. The first evaporator is located in the CTC reactor and the second one in the flue gas duct. The live steam from the boiler is led through the turbine to get mechanical power 
which is transformed into electricity in the generator. The heat from the turbine exhaust steam is utilized in the CFB dryer to reduce the moisture content of the sludge before it is burned in the CTC reactor. This increases the electric power output and efficiency of the plant. The returning condensate from the dryer is pumped back to the boiler to complete the cycle. The plant has one open feed water pre-heater (feed water tank) using saturated water from the drum as the heat source.

The CTC reactor and CFB dryer are both equipped with a built-in cyclone for separating particles from the gas flow. Despite this, some particles leave the boiler with the flue gases and hence, flue-gas clean-up is necessary before admitting the gases into the atmosphere. In calculating the plant performance, complete separation is assumed in the cyclones to simplify the model, and therefore, all ash has to be removed from the bottom of the reactor.

At the design state, the DS content of the sludge entering the dryer is selected so that all heat from the plant is consumed in the drying process. This value is designated as the minimum DS content.

Simulation models have been developed and programmed for the dryer and reactor using a commercial steady-state process simulator (IPSEpro ver 4.0). After this, the developed component models have been combined with the standard models from the software to set up a process model for the plant.

Table 2. Component specifications for the plant.

\begin{tabular}{ccc}
\hline DS content of dried sludge & $(\mathrm{m-} \%)$ & 90 \\
\hline Air ratio in combustion & $(-)$ & 1.4 \\
\hline Flue gas temperature after CTC reactor & $\left({ }^{\circ} \mathrm{C}\right)$ & 850 \\
\hline Stack temperature & $\left({ }^{\circ} \mathrm{C}\right)$ & 230 \\
\hline Live steam temperature & $\left({ }^{\circ} \mathrm{C}\right)$ & 470 \\
\hline Live steam pressure & $(\mathrm{bar})$ & 40 \\
\hline Backpressure & $(\mathrm{bar})$ & 4 \\
\hline Turbine isentropic efficiency & $\mathbf{( \% )}$ & 68.0 \\
\hline Mechanical efficiency (incl. gearbox) & $\mathbf{( \% )}$ & 90.2 \\
\hline Generator efficiency & $\mathbf{( \% )}$ & 95.0 \\
\hline Auxiliary power factor & $\mathbf{( \% )}$ & 95.0 \\
\hline
\end{tabular}

At reference conditions, the composition of the dry sludge is selected according to the example values given in Table 1 . As the lower heating value, a value of $29.5 \mathrm{MJ} / \mathrm{kg}$ is used for the dry ash-free part. This corresponds to $23 \mathrm{MJ} / \mathrm{kg}$ for dry solids when the ash content is $22 \%$. The specifications for the plant components reflect the typical values of small-scale plants and are summarized in Table 2.

The plant is designed to process municipal sewage from a community of 150,000 inhabitants. Using an average dry solids yield of $36 \mathrm{~kg}$ per capita and 8,000 operating hours for the plant annually, this corresponds to the dry solids mass flow rate of $0 . \$ 88 \mathrm{~kg} / \mathrm{s}$ during plant operation. In further simulations, the mass flow rate of dry solids is kept constant while the DS content is varied so that no external cooling or heat is required. 


\section{RESULTS}

Table 3 presents the main performance characteristics of the developed plant at reference conditions. The obtained electric efficiency of the plant is relatively high, owing to the use of low temperature-level heat for drying the sludge thermally before combustion. This increases the heat production in combustion and consequently, electric power yield. At the same time, the heat input is determined according to the heating value of the incoming wet sludge.

The performance of the plant depends on the incoming sludge and selected process parameters. The sensitivity against sludge properties is considered in Figure 4 presenting the effiect of lower heating value and ash content on the performance. In the study, the heating value is determined for dry ash free sludge and therefore the effiect of ash content is straightforward: increasing the amount of ash decreases the heat that is released by burning sludge with the given mass flow rate of dry solids. This is indicated by decreased electric power and efficiency as well as increased minimum DS content. The ash content also affects the minimum heating value that can be allowed for the plant to achieve its designed operating conditions. Due to incineration regulations, the temperature of the flue gas is selected to be $850 \mathrm{aC}$ in the secondary combustion in the CTC reactor. A decrease in the heating value decreases the thermal power allocated for the first evaporator inside the reactor. The left ends of the curves with constant ash content indicate the minimum heating values where the power is decreased to zero. In practice, this means that if the heating value remains below the minimum, the temperature level of the flue gases in the secondary combustion cannot be maintained.

Table 3. Performance data for the plant at reference conditions.

\begin{tabular}{lll}
\hline Minimum dry solids content of sludge & $(\mathrm{m}-\%)$ & 14.2 \\
\hline Net electric power & $(\mathrm{kW})$ & 410 \\
\hline Net electric power as per 1,000 inhabitants & $(\mathrm{kW})$ & 2.7 \\
\hline Electric efficiency & $(\mathbf{\%})$ & 26.7 \\
\hline
\end{tabular}

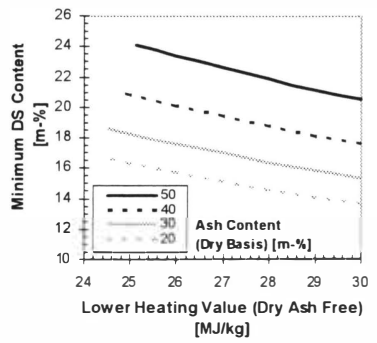

(a)

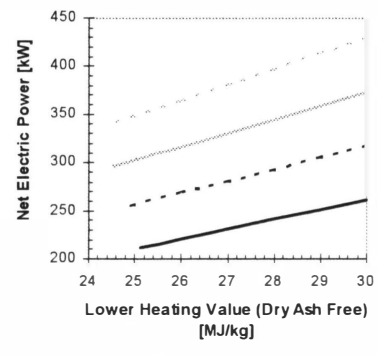

(b)

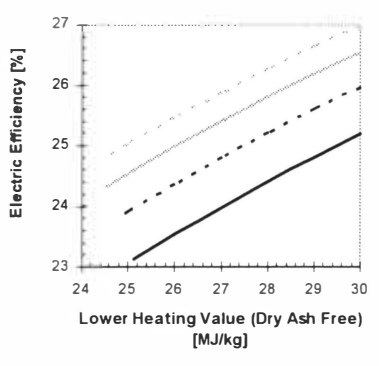

(c)

Figure 4. Effect of lower heating value and ash content on the minimum DS content (a), net power output (b), and electric efficiency (c). 
Figure 5 presents the sensitivity of the plant performance against the main process parameters: live steam pressure and temperature, backpressure and turbine isentropic efficiency. In varying the pressure levels, the relative pressure losses in the steam cycle are kept constant. As the figure shows, the studied plant parameters have only a minor effiect on the minimum DS content. From the parameters, live steam pressure, backpressure and isentropic efficiency have a strong effect on both electric power and efficiency. Compared with these, the effect of live steam temperature is of minor importance.

\section{DISCUSSIONS}

The modeled process produces electricity with higher efficiency than typical small-scale steam power plants or the incineration processes. However, when using sludge as the fuel, most of the cash-flow during operation comes from the sludge acceptance fee and hence, the electric efficiency does not pay such vital role for the plant economy as is the case with conventional power plants using market-priced fuels. High generation efficiency is essential because, globally, electricity consumption increases more rapidly than the demand for heat, and electricity is easier to transmit from waste treatment plants that are often located at a distance from residential areas. Thus, integration of sludge treatment and electricity production can promote commercialization of distributed power generation.
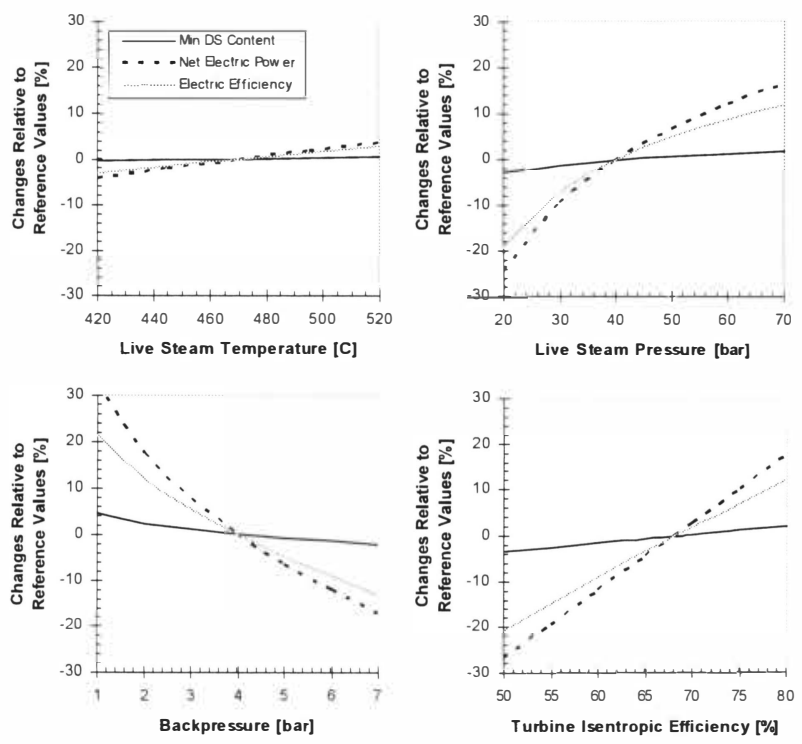

(c)

(d)

Figure 5. The dependency of minimum DS content, net power output, and electric efficiency on live steam temperature (a), live steam pressure (b), backpressure (c), and turbine isentropic efficiency $(d)$. 
In the introduced case, the DS content of the wastewater sludge needed for production of electricity was lower than the general DS content of sludge after mechanical drying. This means that aiming at this type of thermal treatment would require some changes to be made in the pretreatment of the sludge. In the beginning of the study it was considered that lowering of the dewatering demand would save energy and investment costs in mechanical drying. The suppliers and operators of drying equipment seem to suggest that it is not easy to control the operation of the mechanical drying process in a way to change the DS content after the process [9]. The properties of the sludge mostly influence the solids content of the dried sludge. The changing of the operational parameters to make wetter product sludge does not seem to affiect significantly the consumption of energy in the mechanical dewatering process. Another possibility to fix the DS content of sludge for sheer electricity production is to mix mechanically dried sludge with sludge coming straight from the thickener. The proportions of the mass flows have to be such that the suitable DS content will be achieved. In this case, it may be rational to place the thermal treatment plant close to the source of the wettest sludge to avoid extra costs and fuel consumption caused by transportation.

\section{CONCLUSIONS}

The modeling of the process showed that it is possible to produce electricity with relatively high efficiency, using sewage sludge having lower than $20 \%$ DS content, and utilizing all the backpressure heat for drying. The advantages of decreased mechanical dewatering of sludge can be identified in certain special cases only.

In economic terms, the produced electric power of sludge-only combustion seems to be low when the population of the sludge collection region is less than 150.000 (or sludge production $<5400 \mathrm{t} / \mathrm{yr}$ DS). The economics of electricity production are significantly improved when the power is increased above $1 \mathrm{MW}$. It is therefore important to study the possibilities to increase power using local solid recovery fuels and biofuels at the same plant.

Additional fuels and normal DS content after mechanical dewatering increase the thermal energy production so that also surplus heat is produced. Heat can be utilized, for example, in industrial processes or in the drying of wet biofuels if the district heating network is too far from the sludge treatment plant. Integration of sludge treatment to energy production from local by-products and biofuels may increase the profitability of distributed CHP production. The use of other fuels in the process makes it possible also to take the thermally dried and stabilized sludge out from the process without burning, if the utilization of its nutrient content is rational. These issues will be discussed in the forthcoming articles of the present authors.

\section{ACKNOWLEDGEMENTS}

The research has been financed by the DENSY technology program of the Finnish Funding Agency of Technology and Innovation, and Finnish companies (Biolan Oy, Einco Oy, Enmac Oy, Etelä-Karjalan jätehuolto Oy, Laitex Oy, Lappeenrannan Energia Oy and The Switch Oy) and the city of Lappeenranta. The process described in this study is developed into commercial use by Einco Oy, the owner the industrial property rights of the technology.

\section{REFERENCES}

[1] Urban wastewater treatment directive 91/171/EEC.

[2] Council Directive 1999/31/EC of 26 A pril 1999 on the landfill of waste. 
[3] Council Directive 86/278/EEC of 12 June 1986 on the protection of the environment, and in particular of the soil, when sewage sludge is used in agraculture. Official Journal L 181, 04/07/1986 P. 0006a- 0012.

[4] Werther, J., Ogada, T., 1999. Sewage sludge combustion. Progress in energy and combustion science, 25, 55-1 d2.

[5] Renner, R., 2000, Sewage Sludge, Pros \& Cons, The United States and the European nations are far apart on their views of what constitutes safe management., Environmental Science \& Technology, $3 t$ - I.19 loct00.

[6] Douglas, M., 2000. Puhtaus ja vaara. Ritualistisen rajanvedon analyysi. Suom. Blom, Virpi \& Hazard, Kaarina. Vastapaino, Tampere.

[7] Lehtonen, Turo-Kimmo, 2006. Tavaroiden kanssa. Kulutustutkimus ja materiaalisuus. Sosiologia 4/2006, Vol. 43, p.306-318. Westermarck-seuran julkaisu.

[8] Tchobanoglous, G., Burton, F., Stensel, H.D., 2003. Wastewater Engineering, Treatment and Reuse. Fourth Edition, McGraw-Hill, New York.

[9] Kakko, K., 2007. Yhdyskuntalietteen käsittely ennen termistä kuivausta ja polttoa. Diplomityö, Lappeenrannan teknillinen yliopisto, Lappeenranta, 2007. (The treatment of municipal sewage sludge before thermal drying and incineration, Master's Thesis, Lappeenranta University of Finland, in Finnish). 